\title{
Comparison of the two alternative early life-history strategies of the Antarctic fishes Gobionotothen gibberifrons and Lepidonotothen larseni
}

\author{
James J. Ruzicka* \\ Department of Oceanography, School of Ocean and Earth Sciences and Technology, University of Hawaii, 1000 Pope Rd, \\ Honolulu, Hawaii 96822, USA
}

\begin{abstract}
Two major early life-history strategies of notothenioid fishes in the lower Antarctic are identified based upon the length of pelagic development: species that complete pelagic development within 1 summer season ('summer larvae') and species with extended pelagic development that continues over winter months ('winter larvae'). These 2 life-history strategies were compared using otolith techniques to reveal growth histories, hatching periods, and development rates of larval Gobionotothen gibberifrons (summer larvae) and Lepidonotothen larseni (winter larvae) from the Antarctic Peninsula (summer 1986/87) and South Georgia (summers 1987/88 and 1988/89). Back-calculated growth over the first $40 \mathrm{~d}$ after hatching was modeled exponentially and instantaneous growth rates (r) were calculated. Both species grew at similar rates with respect to length $(r=0.01)$ and with respect to weight $(r=0.02$ to 0.03$)$. The hatch period of both species was delayed of the Antarctic Peninsula (lateNovember to mid-December) compared to South Georgia (early to mid-November), as is the onset of the productive season at higher latitudes. Summer larvae have no growth advantage but do develop more quickly than winter larvae, offering the ability to reduce the time spent in a vulnerable life-history stage. As currently hypothesized, winter larvae may take advantage of an extended period for growth, using pelagic resources unavailable to summer larvae, or recruiting to the demersal environment when competition from summer recruits is lowest.
\end{abstract}

KEY WORDS: Gobionotothen gibberifrons - Notothenia gibberifrons - Lepidonotothen larseni - Nototheniops larseni - Larvae - Otoliths - Hatch period Growth

\section{INTRODUCTION}

The Antarctic marine environment is cold and very productive, but highly seasonal; phytoplankton productivity is largely limited to the short summer season (El-Sayed 1985). Low phytoplankton concentration during winter, alone insufficient to support Antarctic planktotrophic larvae (Olson et al. 1987), is likely the strongest common selective pressure upon the biology of Antarctic fauna (Clarke 1988). A common set of life-history adaptations has been observed among Antarctic benthic invertebrates: large yolky eggs, low fecundities and reduced reproductive effort, brood-

·E-mail: ruzicka@hawaii.edu protection, direct development of large larvae, limited or no pelagic development, and slow growth (Thorson 1950, Amaud 1977, White 1977, Clarke 1979, 1983, Picken 1980j. These adaptations, as a group, have been generalized as 'Thorson's Rule'.

Fish are also important members of the benthic fauna and show similar adaptations except that all species have pelagic larvae (North \& White 1987, Kock \& Kellermann 1991). As with invertebrates, the presumed food limitation during the winter season was long believed to be the single most important factor shaping the early life-history strategies of fish. Larvae were hypothesized to begin feeding in the plankton at the time of peak prey abundance (Everson 1984) and subsequent pelagic development would likely be restricted to the summer season (Marshall 1953). 
Our understanding of the true nature of the pelagic environment, especially during winter months, is improving. Evidence now suggests that year round the pelagic environment is not as hazardous to larval development as originally thought. Pelagic development is, in fact, no less common among some groups of Antarctic benthic invertebrate larvae than elsewhere (Pearse et al. 1985, 1991, Pearse \& Bosch 1986), and many larval fish have very long pelagic development stages that continue over winter (Kellermann 1986, 1989a). A closer look at the lifehistory patterns displayed by larval Antarctic fish will help us identify how both the environment and inter-specific interactions shape larval development strategies.

The Antarctic fish community is highly endemic and dominated by a single suborder, the Notothenioidei, which accounts for more than $95 \%$ of the individuals in most coastal areas (Kock 1992). Most Notothenioidei are demersal and restricted to the continental slopes and shelves where they have diversified to fill niches that in other ecosystems are filled by many fish taxa (Eastman 1991, 1993).

The early life-history strategies of the Notothenioidei may be grouped by the number and size of larvae produced, altricial or precocial development (see FleglerBalon 1989), and the duration of the pelagic period. Kock \& Kellermann (1991) have identified 3 strategies: (1) species that produce few, large larvae (precocial) with pelagic development independent of season, and (2) species that produce many small larvae (altricial) with pelagic development either restricted to the productive summer months or (3) extended over the winter months.

Precocial larvae hatch from large $(2.5$ to $5.0 \mathrm{~mm}$ ) eggs that are produced in relatively small numbers. The larvae are large and well developed when they begin feeding, giving them the ability to take advantage of the patchy distribution of larger zooplankton and ichthyoplankton and better ability to escape predators (Kock 1985, Kellermann 1986). Precocial larvae include the Channichthyidae, Artididraconidae, the larger Nototheniidae (particularly the genera Trematomus and Pagothenia), and most Bathydraconidae (Kock \& Kellermann 1991). Precocial larvae are represented by species with different hatching periods throughout the year and include all species that hatch in winter and all species from the higher Antarctic latitudes (ibid.).

Altricial larvae hatch from small (0.8 to $2.5 \mathrm{~mm}$ ) eggs that are produced in large numbers. In favorable conditions many more altricial larvae than precocial larvae may survive to settlement. However, altricial larvae hatch and begin feeding at a small, relatively undeveloped state, making them highly vulnerable to starvation and predation. These species (mainly Nototheniidae) spawn in late winter and spring and hatch exclusively in the spring and summer seasons. Kock \& Kellermann (1991) identify this as the most prevalent reproductive strategy in the lower Antarctic latitudes.

Altricial larvae include 'summer larvae', species that complete pelagic development entirely within the brief productive period of the spring and summer season, and 'winter larvae', all species that remain in the water-column over winter. Among the Nototheniidae, summer larvae include Gobionotothen gibberifrons, Trematomus newnesi, and Lepidonotothen nudifrons; and winter larvae include Lepidonotothen larseni, Lepidonotothen kempi, Gobionotothen marionensis, and Trematomus scotti (Kellermann 1989a, b, Kock \& Kellermann 1991).

The focus of this research is a comparison of the 2 alternative altricial life-history strategies in terms of hatch period, growth, and development rate. Summer larvae are hypothesized to have evolved to take advantage of elevated prey levels during the summer, allowing for relatively rapid growth and development rates to achieve an ecologically viable size for settlement in a relatively short time. This would minimize the time spent in a hazardous pelagic environment and a vulnerable life stage when much of the regulation of year-class strength occurs (Thorson 1950. Houde 1987). Three hypotheses may explain the adaptive significance of multi-season development (i.e. winter larvae). (1) Larvae are able to take advantage of winter resources unavailable to single season developers at a time when competition is reduced (Kock \& Kellermann 1991). (2) An extended pelagic phase allows a prolonged period for growth that allows larvae to settle at a larger size and more developed stage or compensates for an inability to grow to a minimum settlement size and development stage before the end of summer. (3) A prolonged pelagic phase allows new 'recruits' to enter the demersal environment at a different time of year than summer larvae when inter-specific competition in the new habitat is lowest (Kellermann \& Schadwinkel 1990).

Data derived from otoliths were used to compare the timing of the hatch, growth rates, and development rates of larvae of 2 species, Gobionotothen gibberifrons (summer larvae; formerly Notothenia gibberifrons) and Lepidonotothen larseni (winter larvae; formerly Nototheniops larseni), from 2 different regions, the Bransfield Strait region of the Antarctic Peninsula and South Georgia. The hypotheses presented here are difficult to test directly, but we can tell which hypotheses are consistent with the early life-history data collected from otoliths and which hypotheses require modification. 


\section{MATERIALS AND METHODS}

Field collection of samples. Larvae for this work were made available from 3 summer cruises, 1 along the west coast of the Antarctic Peninsula and 2 in the coastal waters surrounding South Georgia.

The Research on Antarctic Coastal Ecosystem Rates program (RACER) sampled a $250 \times 100 \mathrm{~km}$ grid of stations in the western Bransfield Strait off the Antarctic Peninsula (Huntley et al. 1991). Stations were sampled with either oblique tows in the upper $50 \mathrm{~m}$ using a $0.7 \mathrm{~m}$ diameter bongo net with 330 and $505 \mu \mathrm{m}$ mesh (69 'fast' stations) or in 2 discrete layers $(0-100$ and $100-200 \mathrm{~m}$ ) with oblique tows of paired opening and closing Nansen nets with $330 \mu \mathrm{m}$ mesh (25 'slow stations). RACER began in the summer of 1986/87 with a series of 4 cruises in December, January, February, and March aboard the RV 'Polar Duke'. One half $(\mathrm{n}=63$ Gobionotothen gibberifrons, $\mathrm{n}=18$ Lepidonotothen larsenil of the larvae from the January cruise (January 19-February 2, 1987) was preserved in 100\% methyl alcohol and examined in this work. The size and geographic distribution of the remainder were reported by Loeb (1991); there was no substantial difference in the mean length of larvae in the 2 sub-groups

The 2 cruises off South Georgia were both demersal fish surveys of the US Antarctic Marine Living Resources program (US AMLR). The first cruise was a joint American-Polish study aboard the Polish RV 'Professor Siedlecki' (December 18, 1987, to January 10, 1988). The samples analyzed in this study were collected from 13 stations using an experimental technique where larval fish were caught in conjunction with bottom trawl operations in coastal waters around South Georgia and at Shag Rocks. Four plankton nets $1505 \mu \mathrm{m}$ mesh and $12 \mathrm{~mm}$ mesh with a $505 \mu \mathrm{m}$ liner) were placed at various positions $(4,12,16$, and $28 \mathrm{~m})$ from the head rope of a commercial bottom trawl. After capture, larvae $(\mathrm{n}=11$ Gobionotothen gibberifrons, $\mathrm{n}=499$ Lepidonotothen larseni) were preserved in isopropyl alcohol.

The second cruise of South Georgia was aboard the NOAA ship 'Surveyor' (January 4 to February 2, 1989). This cruise sampled the upper $180 \mathrm{~m}$ in a grid of $47 \mathrm{sta}$ tions around the island using a $0.6 \mathrm{~m}$ diameter bongo net with $505 \mu \mathrm{m}$ mesh. Additional samples were collected with several 'yo-yo' tows (where the bongo was brought up and down repeatedly in the upper $30 \mathrm{~m}$ ) and with the use of a $2 \mathrm{~m}$ Isaacs-Kidd midwater trawl. The larvae $(\mathrm{n}=$ 64 Gobionotothen gibberifrons, $\mathrm{n}=278$ Lepidonotothen larseni) were preserved in buffered isopropyl alcohol.

A sub-sample of the larvae available from each cruise was randomly selected for detailed otolith analysis. Additional samples were randomly chosen for more measurements of gross otolith dimensions, larval morphometrics, and larval development state.
Morphometrics. Measurements of standard length (from the tip of the snout to the base of the caudal fin) were taken with calipers to the nearest $0.1 \mathrm{~mm}$. To measure dry weight, samples were placed in a storage desiccator and allowed to dry at room temperature for $1 \mathrm{wk}$ and then weighed upon a Cahn microbalance to the nearest $0.001 \mathrm{mg}$. The samples were then returned to the desiccator and re-weighed after 6 to $24 \mathrm{~h}$. This was repeated 3 times and the mean weight of each sample was used.

Development state was noted by observing readily visible changes in the morphology of external features (pelvic fins, pectoral fins, dorsal and anal fins, and flexion state). The rate of development may be described by bracketing the timing (or size range) of each development event between the youngest (or smallest) observed larva to have attained a specific development state and the oldest (or largest) larva to have not yet reached that state.

Otolith techniques. Age (the estimated ring count) and otolith growth histories (the otolith radius at each sequential ring) were obtained from sagittal otoliths excised from each larva. Otolith data were collected with light microscopy using a video-coordinate digitizing system. A randomly selected sub-sample was also examined with scanning electron microscopy (SEM). All ring counts and measurements were made along the most clearly readable axis. The number of rings within any unreadable region along the selected axis was estimated as a function of the distance from the otolith's center and the average ring width at that radius among other otoliths from the same group. Detailed otolith methodologies are described in Ruzicka \& Radtke (1995).

A comparison of the estimated ring counts of individual Lepidonotothen larseni and Gobionotothen gibberifrons otoliths examined with both light microscopy and SEM (selected from each of the same sample groups considered here) has shown that SEM counts are usually greater (Ruzicka \& Radtke 1995). This difference was significant among the $L$. larseni from South Georgia 1987/88 and is attributed to the lower resolving power of light microscopy (ibid.). Ages, hatch dates, and growth rates estimated from both light microscopy and SEM derived data are presented together.

\section{RESULTS}

\section{Morphometrics}

The standard lengths and dry weights of Gobionotothen gibberifrons and Lepidonotothen larseni were distributed normally; these distributions are summarized in Table 1. No correction was made for sample 
Table 1. Gobionotothen gibberifrons and Lepidonotothen larseni. Mean standard lengths and weights ( \pm 1 SD) of larvae collected off South Georgia in the summers of $1987 / 88$ and 1988/89 and within the Bransfield Strait off the Antarctic Peninsula in the summer of $1986 / 87$. Data are distributed normally

\begin{tabular}{|c|c|c|}
\hline & $\begin{array}{l}\text { Standard length } \\
(\mathrm{mm})\end{array}$ & $\begin{array}{l}\text { Dry weight } \\
\text { (mg) }\end{array}$ \\
\hline \multicolumn{3}{|c|}{ Gobionotothen gibberifrons } \\
\hline $\begin{array}{l}\text { South Georgia } \\
1987 / 88\end{array}$ & $\begin{aligned} 12.19 & \pm 2.38 \\
(\mathrm{n} & =1.1)\end{aligned}$ & $\begin{array}{c}1.42 \pm 0.49 \\
(\mathrm{n}=11)\end{array}$ \\
\hline $\begin{array}{l}\text { South Georgia } \\
1988 / 89\end{array}$ & $\begin{aligned} 22.49 & \pm 2.01 \\
(\mathrm{n} & =64)\end{aligned}$ & $\begin{aligned} 15.73 & \pm 4.71 \\
(\mathrm{n} & =54)\end{aligned}$ \\
\hline $\begin{array}{l}\text { Peninsula } \\
1986 / 87\end{array}$ & $\begin{array}{c}16.64 \pm 1.76 \\
(n=63)\end{array}$ & $\begin{aligned} 3.61 & \pm 1.62 \\
(\mathrm{n} & =55)\end{aligned}$ \\
\hline \multicolumn{3}{|c|}{ Lepidonotothen Iarseni } \\
\hline $\begin{array}{l}\text { South Georgia } \\
1987 / 88\end{array}$ & $\begin{array}{c}11.88 \pm 1.44 \\
(\mathrm{n}=30)\end{array}$ & $\begin{array}{c}0.45 \pm 0.16 \\
(\mathrm{n}=32)\end{array}$ \\
\hline $\begin{array}{l}\text { South Georgia } \\
1988 / 89\end{array}$ & $\begin{array}{c}17.61 \pm 3.18 \\
(\mathrm{n}=49)\end{array}$ & $\begin{aligned} 4.42 & \pm 1.96 \\
(\mathrm{n} & =48)\end{aligned}$ \\
\hline $\begin{array}{l}\text { Peninsula } \\
1986 / 87\end{array}$ & $\begin{array}{c}16.28 \pm 1.53 \\
(n=17)\end{array}$ & $\begin{array}{c}1.17 \pm 0.38 \\
(\mathrm{n}=18)\end{array}$ \\
\hline
\end{tabular}

shrinkage in this work. Comparison of fresh and preserved lengths of $L$. Iarseni (Ruzicka unpubl. data) showed that the larvae shrank very little after 3 yr of storage in $90 \%$ ethanol, only $2.3 \%( \pm 1.7 \%, \mathrm{n}=22)$ on average. However, the degree to which the larvae shrank before preservation is unknown.

The presence of yolk could not be detected in any larvae studied in this work. Flexion occurred early in Gobionotothen gibberifrons and was observed in all larvae including the youngest (22 d) and smallest $(8.4 \mathrm{~mm})$. Flexion in Lepidonotothen larseni occurred between 43 and $52 \mathrm{~d}(11.4$ to $18.1 \mathrm{~mm}$ ), the youngest post-flexion and the oldest pre-flexion larvae, respectively. All observed $G$. gibberifrons had visible rays forming in the dorsal, anal, and pectoral fins. Rays first became apparent in these fins slightly later in $L$. larseni, between 25 and $47 \mathrm{~d}$ old (10.2 to $16.4 \mathrm{~mm}$ ). All fins had become well formed in the oldest $G$. gibberifrons observed, 54 to $79 \mathrm{~d}$ old (18.6 to $27.0 \mathrm{~mm}$ ). In contrast, pelvic fin buds had only just appeared in the oldest and largest L. larseni, 68 to $78 \mathrm{~d}$ old (16.7 to $23.2 \mathrm{~mm}$ ). These ages are estimated from ring counts on otoliths examined under light microscopy.

\section{Hatch dates}

Assuming that otolith ring counts accurately reflect age in days, the approximate hatch date may be determined by subtracting the estimated age from the capture-date of each larva (Figs $1 \& 2$, Table 2). The otolith data show that during any particular year, hatching of both species occurs over a period of about

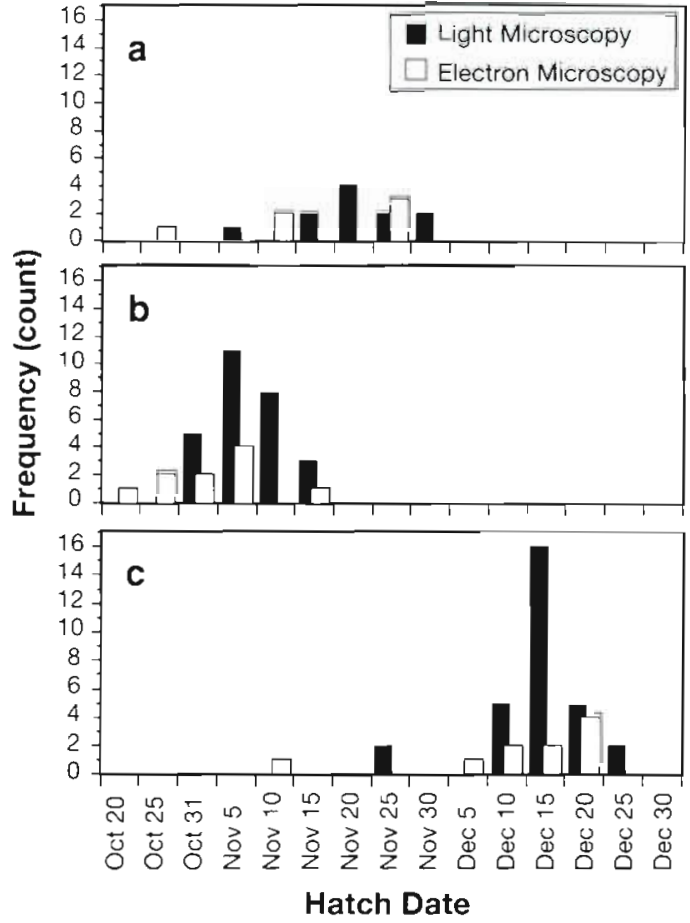

Fig. 1. Gobionotothen gibberifrons. Hatch date distributions (a) South Georgia 1987/88; (b) South Georgia 1988/89; (c) Antarctic Peninsula 1986/87

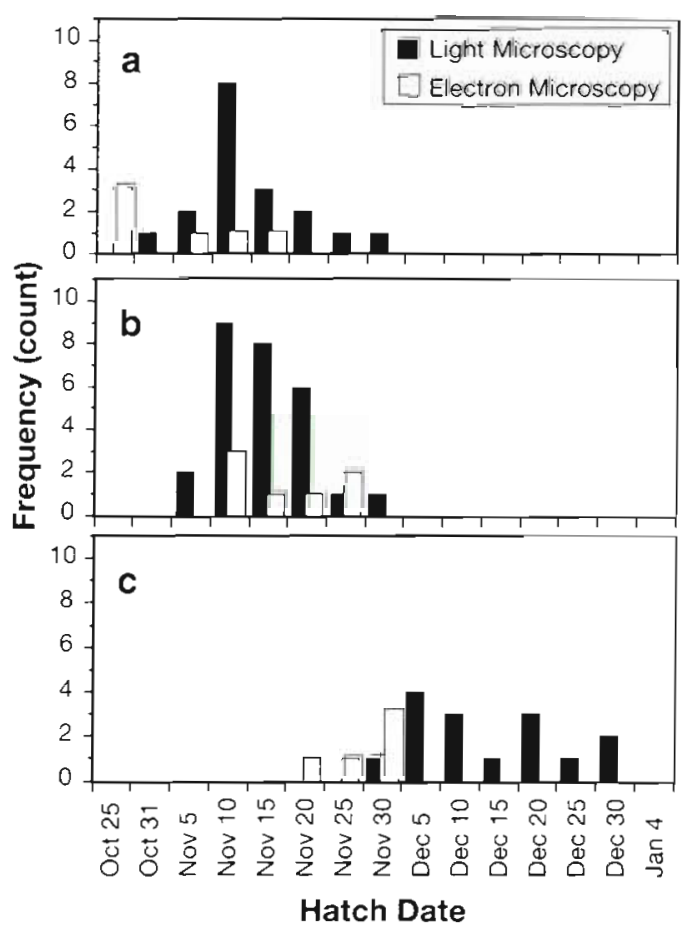

Fig. 2. Lepidonotothen larseni. Hatch date distributions. (a) South Georgia 1987/88; (b) South Georgia 1988/89; (c) Antarctic Peninsula 1986/87 
Table 2. Gobionotothen gibberifrons and Lepidonotothen larseni. Mean age and hatch dates ( 1 SD) of larvae from South Georgia (1987/88 and 1988/89) and the Bransfield Strait off the Antarctic Peninsula (1986/87) as estimated from otoliths examined under light microscopy and SEM

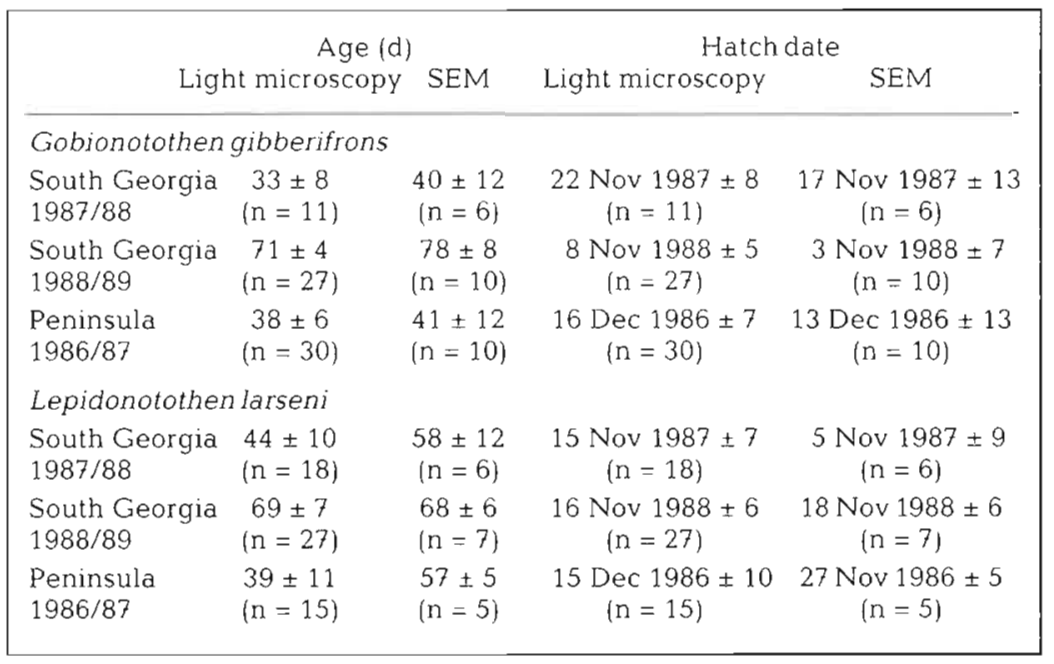

tween otolith size and larval size for larvae of the same species caught during different years (but within the same region).

Analysis of covariance (Snedecor \& Cochran 1980) was used to compare the separate regression models generated from both cruises off South Georgia (Table 4). The 2 years' regression models of standard length against otolith diameter for South Georgian Lepidonotothen larseni did not differ significantly. The 2 models for South Georgian Gobionotothen gibberifrons differed significantly at $\alpha=0.05$, but the pooled model was still considered more accurate in view of the very weak correlation between the otolith diameters and standard lengths of the $1988 / 89$ samples. The model generated from the pooled South Georgian

1 mo. The variability of Lepidonotothen larseni hatch dates was only slightly greater than that of Gobionotothen gibberifrons, suggesting that there is just 1 peak hatch period for both species.

\section{Growth}

If a significant correlation exists between somatic growth and otolith growth, then detailed knowledge of an otolith's growth history (integral to the otolith's structure) offers detailed knowledge of the growth history of the individual fish from which it came. This method is commonly used to back-calculate fish sizes and track larval growth through time (e.g. Wilson \& Larkin 1982, Penney \& Evans 1985, Nishimura \& Yamada 1988, Thorrold \& Williams 1989, Jenkins \& Davis 1990, May \& Jenkins 1992).

The relationships between otolith size (longest diameter) and fish size at the time of capture are shown in Figs. 3 (standard length) \& 4 [In(dry weight)]. The linear least-squares regression method was used to describe the relations (Table 3). Since the purpose was to predict one variable (larval size) from the value of another (otolith diameter), a Model I rather than Model II regression was applied (Sokal \& Rohlf 1981).

The range of otolith and somatic sizes from each South Georgian cruise was narrow. Combining data from the 2 cruises provided a more precise description of the relation between otolith and somatic size, which was derived from data covering nearly the complete size range in which growth histories are calculated. The validity of pooling data from these 2 cruises rests on the assumption that the same relationship exists be-
G. gibberifrons data did not differ significantly from the model generated from the unpooled 1987/88 samples (equal slopes, $p=0.1275$; equal intercepts, $p=0.9270$ )

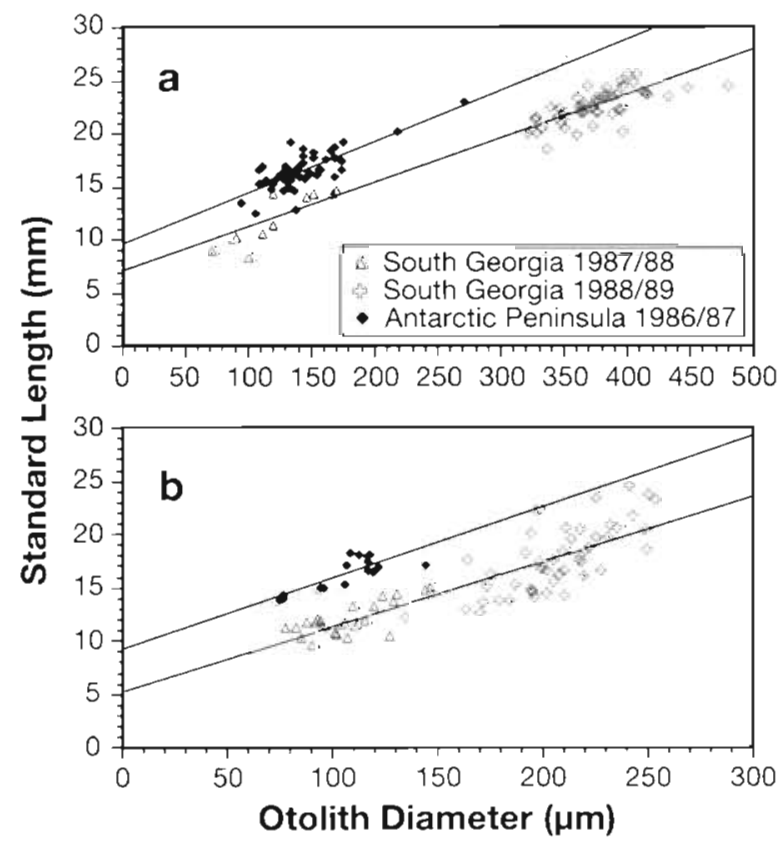

Fig. 3. Gobionotothen gibberifrons and Lepidonotothen larseni. Relationships between the otolith diameters (OD) and standard lengths (SL) of larvae collected off the Antarctic Peninsula in the summer of $1987 / 88$ and of South Georgia in the summers of $1987 / 88$ and $1988 / 89$. Data from the 2 South Georgia cruises were pooled. (a) G. gibberifrons: Antarctic Peninsula $\left(\mathrm{SL}=9.5520+\mathrm{OD} \times 0.0480, \mathrm{R}^{2}=0.598\right)$ and South Georgia $\left(\mathrm{SL}=6.8868+\mathrm{OD} \times 0.0418, \mathrm{R}^{2}=0.897\right)$. (b) L. larseni: Antarctic Peninsula $\left(\mathrm{SL}=9.0787+\mathrm{OD} \times 0.0668, \mathrm{R}^{2}=0.628\right)$ and South Georgia ( $\left.S L=5.0777+O D \times 0.0611, R^{2}=0.748\right)$ 


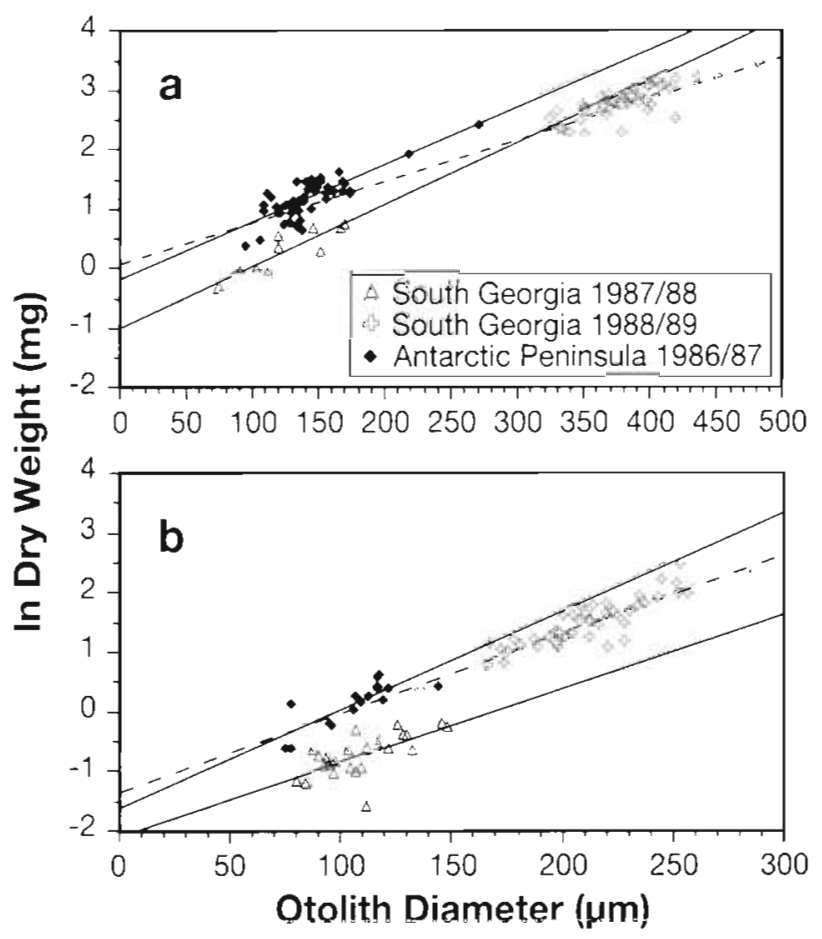

Fig. 4. Gobionotothen gibberifrons and Lepidonotothen larsent. Relationships between the otolith diameters (OD) and ln(dry welght) (lnW) of larvae collected off the Antarctic Peninsula in the summer of $1986 / 87$ and off South Cieorgia in the summers of 1987/88 and 1988/89. (a) G. gibberifrons: Antarctic Peninsula $\left(\ln W=-0.2224+\mathrm{OD} \times 0.0096, \mathrm{R}^{2}=0.649\right)$, South Georgia $1987 / 88\left(\ln W=-1.0555+O D \times 0.0104, R^{2}=0.778\right)$, and South Georgia 1988/89 (dashed line, $\operatorname{In} W=0.1135+\mathrm{OD} \times 0.0068$, $\mathrm{R}^{2}=0.639$ ) (b) L. larseni: Antarctic Peninsula (lnW $=-1.6803+$ $\left.\mathrm{OD} \times 0.0167, \mathrm{R}^{2}=0.659\right)$, South Georgia $1987 / 88(\mathrm{nW}=$ $\left.-2.5285+\mathrm{OD} \times 0.0156, \mathrm{R}^{2}=0.404\right)$, and South Georgia 1988/89

(dashed line, $\ln W=-1.3659+\mathrm{OD} \times 0.0132, \mathrm{R}^{2}=0.793$ )

nor from the unpooled 1988/89 samples (equal slopes, $p=0.0953$; equal intercepts, $p=0.8234$ ). Therefore, the pooled data were used to back-calculate larval lengths for both species. The regressions of $\ln (\mathrm{dry}$ weight) against otolith diameter were clearly significantly different for both species, and larval weights were backcalculated using models generated from unpooled data.

The predicted standard lengths and weights are displayed as growth profiles (Figs. $5 \& 6$ respectively). Growth of individual larvae was modeled exponentially:

$$
\begin{aligned}
l_{\text {age }} & =I_{0} \mathrm{e}^{r \text { (age })} \\
w_{\text {age }} & =w_{0} \mathrm{e}^{r(\text { age })}
\end{aligned}
$$

where age is the number of days from hatching, $l_{\text {age }}$ is the standard length at a given age, $I_{0}$ is the standard length at hatching, $w_{\text {age }}$ is the dry weight at a given age, $w_{0}$ is the dry weight at hatching, and $r$ is the instantaneous growth rate (Table 5). The data were fit linearly using a Model II (geometric mean) regression (Ricker 1973) after back-calculated larval sizes had

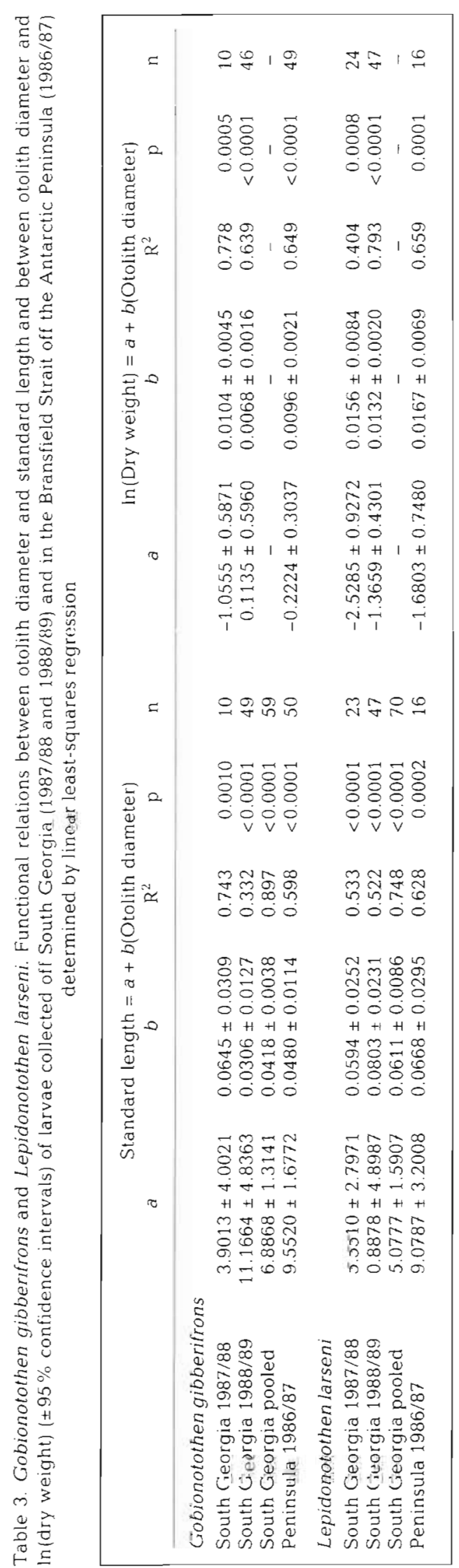


Table 4. Gobionotothen gibberifrons and Lepidonotothen larseni. Results of analysis of covariance to compare the regressions of otolith size against fish size (standard length and dry weight) from samples collected off South Georgia in the summer of $1987 / 88$ with the regressions from samples collected off South Georgia in the summer of $1988 / 89$. Underlined probabilities are considered significant at $\alpha=0.05$

\begin{tabular}{|c|c|c|}
\hline & Standard length & Dry weight \\
\hline \multicolumn{3}{|c|}{ Gobionotothen gibberifrons } \\
\hline $\begin{array}{l}\text { Equality of } \\
\text { slopes }\end{array}$ & $\begin{aligned} F_{\mid 1.55\}} & =4.744 \\
p & =0.0337\end{aligned}$ & $\begin{aligned} F_{|1.52|} & =3.387 \\
p & =0.0714\end{aligned}$ \\
\hline $\begin{array}{l}\text { Equality of } \\
\text { adjusted means }\end{array}$ & $\begin{aligned} F_{\mid 1.561} & =1.041 \\
p & =0.3120\end{aligned}$ & $\begin{aligned} F_{[1,53]} & =8.285 \\
\mathrm{p} & =\underline{0.0058}\end{aligned}$ \\
\hline \multicolumn{3}{|c|}{ Lepıdonotothen larseni } \\
\hline $\begin{array}{l}\text { Equality of } \\
\text { slopes }\end{array}$ & $\begin{aligned} F_{[1,66]} & =0.809 \\
p & =0.3717\end{aligned}$ & $\begin{aligned} F_{\mid 1,67 !} & =0.574 \\
\mathrm{p} & =0.4513\end{aligned}$ \\
\hline $\begin{array}{l}\text { Equality of } \\
\text { adjusted means }\end{array}$ & $\begin{aligned} F_{|1,67|} & =3.706 \\
p & =0.0585\end{aligned}$ & $\begin{aligned} F_{|1,68|} & =36.081 \\
p & <0.0001\end{aligned}$ \\
\hline
\end{tabular}

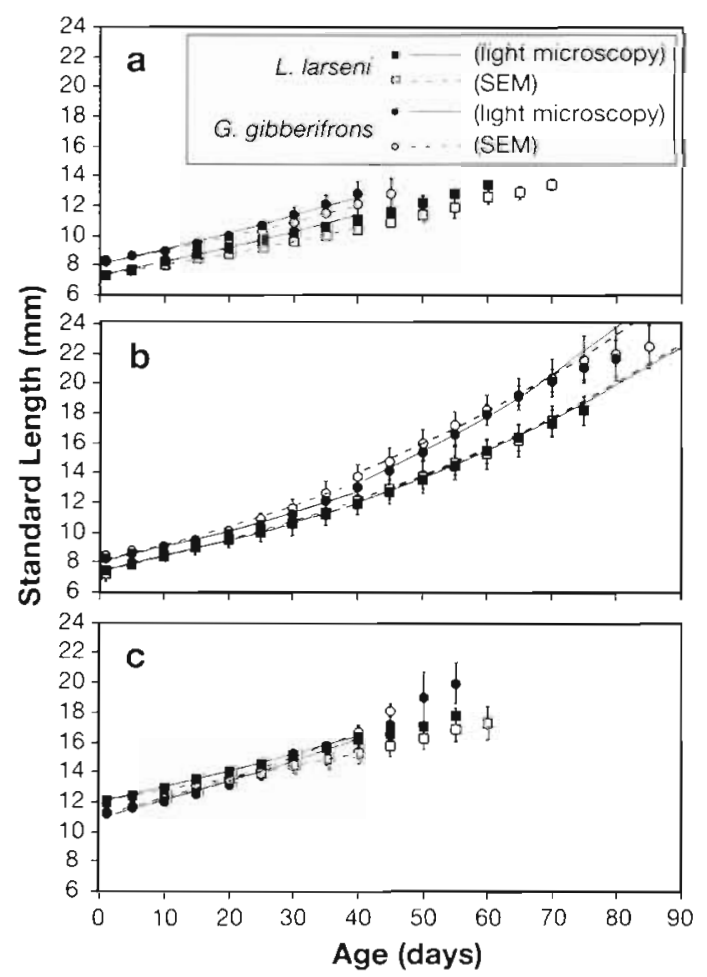

Fig. 5. Gobionotothen gibberifrons and Lepidonotothen larseni. Reconstructed growth histories of G. gibberifrons and L. larseni, with respect to length. Lengths of individual larvae were backcalculated from otolith data derived from light microscopy and SEM. The mean lengths ( $\pm 1 \mathrm{SD})$ are plotted here in $5 \mathrm{~d}$ intervals. Growth of individual larvae over the first $40 \mathrm{~d}$ was modeled exponentially; the mean growth models (Table 5) are overlain upon the back-calculated lengths. (a) South Georgia 1987/88; (b) South Georgia 1988/89 (also showing the growth model after 40 d), (c) Antarctic Peninsula 1986/87 been natural-log transformed. For each group of larvae, the mean correlation coefficient was $>0.95$, for both length and weight models. The individual growth rates within each group were normally distributed.

With respect to both length and weight, the growth rates over the first $40 \mathrm{~d}$ calculated using light microscopy data were significantly greater than rates calculated using SEM data among the Lepidonotothen larseni from South Georgia 1987/88 and the Antarctic Peninsula 1986/87 ( $t$-test, $p<0.05, \alpha=0.05$ ). This is consistent with the observation that very narrow rings $(<0.5 \mu \mathrm{m})$ may be unobserved with light microscopy (Ruzicka \& Radtke 1995).

\section{Testing the back-calculation method}

The model used to reconstruct growth histories may be tested by comparing predicted past size distribu-
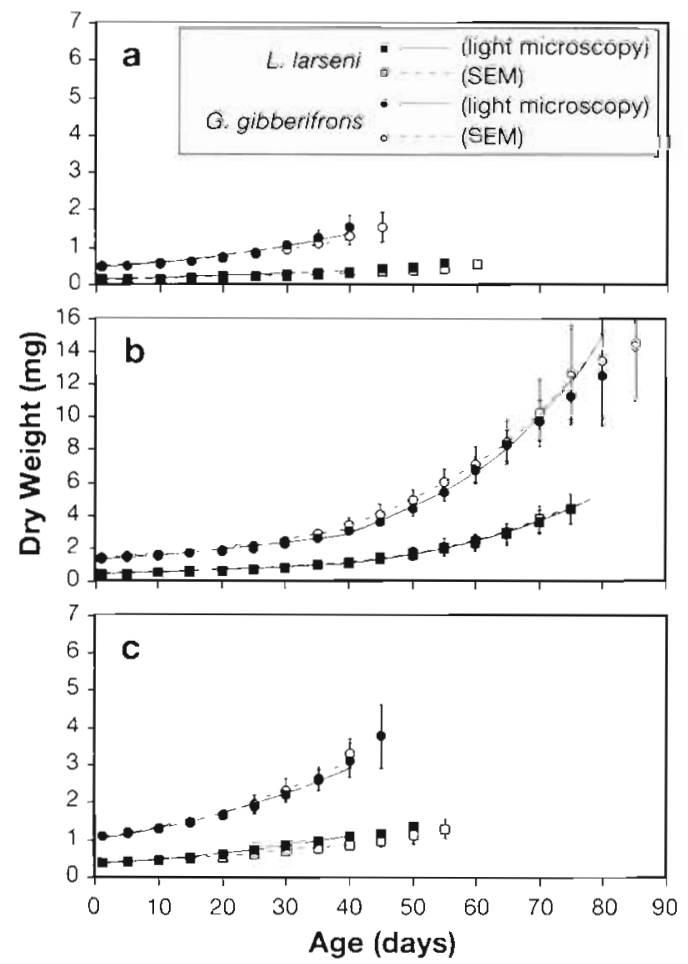

Fig. 6. Gobionotothen gibberifrons and Lepidonotothen larseni. Reconstructed growth histories of $G$. gibberifrons and $L$. larseni, with respect to dry weight. Weights of individual larvae were back-calculated from otolith data derived from light microscopy and SEM. The mean weights ( \pm 1 SD) are plotted here in 5 d intervals. Growth of individual larvae over the first $40 \mathrm{~d}$ was modeled exponentially; the mean growth models (Table 5) are overlain upon the back-calculated weights. (a) South Georgia 1987/88; (b) South Georgia 1988/89 (also showing the growth model after $40 \mathrm{~d}$ ); (c) Antarctic Peninsula 1986/87 


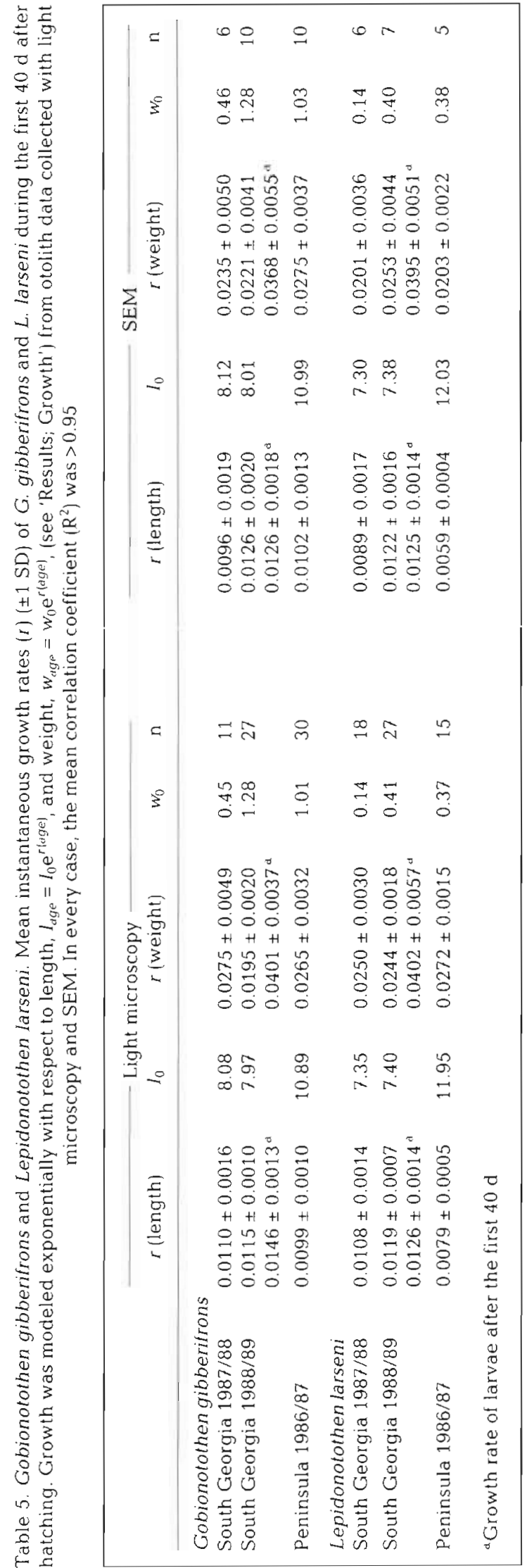

tions with the findings of studies that have sampled from the same cohorts earlier in the season. This is possible with the 1986/87 Antarctic Peninsula cohorts where the RACER program sampled larvae during a series of 4 cruises (December through March). The standard length distributions of both species during each month were reported by Loeb (1991).

Table 6 shows the standard length distribution of each species in December as predicted from the otoliths of larvae caught in January and the actual size distribution of the larvae in December. A Wilcoxon's rank sum test (Hollander \& Wolfe 1973) was employed to compare the predicted standard lengths (counting rings inwards from the outer edge to December 24, the midpoint of RACER sampling) to the actual standard lengths. In the case of Gobionotothen gibberifrons, the difference was not statistically significant whether using light microscopy or SEM derived data. The predicted lengths of Lepidonotothen larseni in December were significantly less than the larvae actually encountered when using light microscopy derived data. The error in the model when using light microscopy is likely to be the result of the lower resolving power of the light microscope and unseen rings. There was no significant difference when SEM data were used.

\section{Inter-specific differences in growth}

Do summer larvae grow faster than winter larvae? In most cases, the mean Gobionotothen gibberifrons instantaneous growth rates were greater than Lepidonotothen larseni growth rates (Table 5). A $t$-test (Moore \& McCabe 1989) was used to make a cohort-by-cohort comparison of the instantaneous growth rates of the 2 species (Table 7). Only G. gibberifrons from South Georgia 1988/89 (older than 40 d, as analyzed under light microscopy) and from the Antarctic Peninsula 1986/87 grew significantly faster with respect to length. With respect to weight, only $G$. gibberifrons from the Antarctic Peninsula 1986/87 (as analyzed under SEM) grew significantly faster than the winter larvae.

\section{Growth in the literature}

Otolith derived growth rates are similar to rates measured by following cohorts through time (Table 8 ). The literature provides some evidence that Gobionotothen gibberifrons grow slightly faster than Lepidonotothen larseni (with respect to length). However, the literature provides no examples where the growth rates of both species were measured together during the same year and in the same region. Growth of $G$. gibberifrons shows great inter-annual variability at South Georgia. 
Table 6. Gobionotothen gibberifrons and Lepidonotothen larseni. Predicted and actual standard length distributions ( $\pm 1 \mathrm{SD}$ ) of larvae in the Bransfield Strait, December 1986, compared with a Wilcoxon's rank sum test $\left(\mathrm{H}_{0}\right.$ : predicted size $=$ actual size; $\mathrm{H}_{1}$ : predicted size $\neq$ actual size). Underlined probabilities are considered significant at $\alpha=0.05$

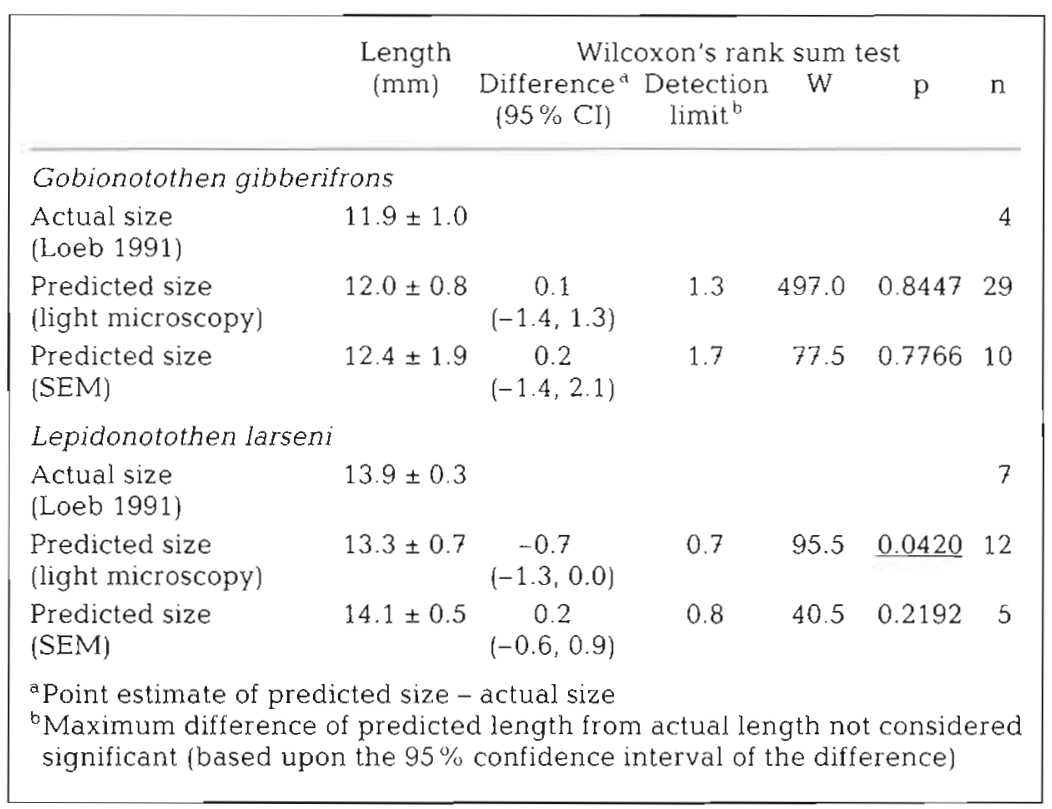

\section{DISCUSSION}

The use of otoliths in this study to accurately measure the age and backcalculate the hatch dates of individual larvae rests upon the assumptions that ring deposition is daily and begins at hatch. In teleost fish, daily rings are common in the otoliths of adults and larvae (Jones 1986, Campana 1989). Daily rings have been experimentally validated in 3 Antarctic species (White 1991): Trematomus newnesi (Radtke et al. 1989), Lepidonotothen nudifrons (Hourigan \& Radtke 1989, Radtke \& Hourigan 1990), and Harpagifer antarcticus (White 1991, citing unpubl. data). There is also indirect evidence of daily ring deposition in Lepidonotothen larseni (Radtke \& Targett 1984). The assumption that ring deposition commonly begins at hatch in the Notothenioidei is supported by the observation that the core edge represents a hatch check in $L$. nudifrons (Hourigan \& Radtke 1989).

However, those years with very slow growth (1977 and 1985) are years when data are restricted to older, larger larvae. Growth rates from the single year available from the Peninsula fall at the lower end of the South Georgian range. Growth rates of peninsular $L$. larseni show little inter-annual variation and are all less than the growth rates around South Georgia. Higher growth rates off South Georgia may be indicative of a more favorable environment for growth.
The use of otoliths to reconstruct growth histories is not without disadvantages. The relation between otolith growth and somatic growth for an entire population is biased if the otolith size of individuals is strongly influenced by their differing rates of somatic growth, decoupling otolith size from somatic size; each individual would then have a unique relation between otolith size and somatic size. Since ring deposition continues even when somatic growth

Table 7. Gobionotothen gibberifrons and Lepidonotothen larseni. A comparison of the instantaneous growth rates ( $r$ ) of summer larvae (G. gibberifrons) and winter larvae (L. larseni) during the first $40 \mathrm{~d}$ after hatching using the $t$-test $\left(\mathrm{H}_{0}: r_{\text {summer }}=r_{\text {winteri }}\right.$ $\left.\mathrm{H}_{1}: r_{\text {summer }}>r_{\text {winter }}\right)$. Instantaneous growth rates with respect to standard length and dry weight were calculated from otolith data collected with light microscopy and SEM. Underlined probabilities are considered significant at $\alpha=0.05$

\begin{tabular}{|c|c|c|c|c|c|c|c|c|}
\hline & \multicolumn{4}{|c|}{ Standard length (mm) } & \multicolumn{4}{|c|}{ Dry weight (mg) } \\
\hline & Difference $^{a}$ & $t$ & p & $\mathrm{df}$ & Difference ${ }^{a}$ & $\vec{t}$ & $\mathrm{p}$ & $\mathrm{df}$ \\
\hline \multicolumn{9}{|l|}{ Light Microscopy } \\
\hline South Georgia 1987/88 & $0.0002 \pm 0.0012$ & 0.34 & 0.3680 & 19 & $0.0025 \pm 0.0035$ & 1.53 & 0.0746 & 14 \\
\hline $1988 / 89$ & $-0.0004 \pm 0.0005$ & -1.70 & 0.9523 & 47 & $-0.0049 \pm 0.0010$ & -9.46 & 1.000 & 51 \\
\hline $1988 / 89^{b}$ & $0.0020 \pm 0.0007$ & 5.44 & $\leq 0.0001$ & 51 & $-0.0001 \pm 0.0026$ & -0.08 & 0.5303 & 44 \\
\hline Peninsula $1986 / 87$ & $0.0020 \pm 0.0005$ & 8.94 & $\leq 0.0001$ & 42 & $-0.0007 \pm 0.0014$ & -1.00 & 0.8382 & 42 \\
\hline \multicolumn{9}{|l|}{ Electron Microscopy } \\
\hline South Georgia 1987/88 & $0.0007 \pm 0.0024$ & 0.67 & 0.2591 & 9 & $0.0034 \pm 0.0057$ & 1.35 & 0.1047 & 9 \\
\hline $1988 / 89$ & $0.0004 \pm 0.0019$ & 0.46 & 0.3273 & 14 & $-0.0032 \pm 0.0046$ & -1.52 & 0.9225 & 12 \\
\hline $1988 / 89^{b}$ & $0.0001 \pm 0.0017$ & 0.13 & 0.4497 & 14 & $-0.0027 \pm 0.0056$ & -1.04 & 0.8413 & 13 \\
\hline Peninsula 1986/87 & $0.0043 \pm 0.0010$ & 9.59 & $\leq 0.0001$ & 11 & $0.0072 \pm 0.0033$ & 4.71 & 0.0003 & 12 \\
\hline
\end{tabular}


the food resource) with little added cost. Alternatively, precise hatch timing may be the result of competitive pressure. North \& White (1987) and Kellermann (1989a) have noted that a succession of different species hatch at different sizes and times. They hypothesized that temporal and size partitioning of larval resources may represent adaptations that have the effect of reducing inter-specific competition for the food resource.

The data presented here and in the literature support the hypothesis that summer larvae generally grow faster than winter larvae. The differences in growth rates can account for fairly large differences in size by the end of summer. For example, a larva that hatches at $10 \mathrm{~mm}$ at the beginning of December and grows at $r=0.010$ (as measured in this study for peninsular Gobionotothen gibberifrons) will reach $34 \mathrm{~mm}$ by early April. The same fish growing at $r=0.006$ (as measured for peninsular Lepidonotothen larseni) will only reach $21 \mathrm{~mm}$ by early April. Not until June will peninsular L. larseni grow larger than $30 \mathrm{~mm}$ (Kellermann 1989b).

Development proceeds more rapidly in Gobionotothen gibberifrons. Within just 1 mo of hatching, the larvae observed here have become post-flexion and have a full complement of developing fins. By the end of summer (April), G. gibberifrons have reached the juvenile stage and are ready to settle (Kellermann 1989a). In contrast, pelvic fin buds have only just appeared in the oldest Lepidonotothen larseni observed in this study, 68 to $78 \mathrm{~d}$ old. L. larseni are found in the pre-juvenile 'transforming larva' stage as late as June (Kellermann 1989b).

Pelagic Gobionotothen gibberifrons have been caught into late March off both the Peninsula and South Georgia, reaching 22 to 26 and 35 to $38 \mathrm{~mm}$, respectively (Efremenko 1983, Kellermann 1989a). Settlement is probably completed by April (Kellermann 1989a). Using the hatch size, hatch date, and growth rate parameters measured in this study, G. gibberifrons larvae settling in the first half of April off the Peninsula will be 33 to $38 \mathrm{~mm}$; off South Georgia, settling larvae will be 31 to $36 \mathrm{~mm}$ and 56 to $58 \mathrm{~mm}$ (in April 1988 and 1989, respectively).

Pelagic Lepidonotothen larseni juveniles continue to grow over winter and settle at a larger size than Gobionotothen gibberifrons. Off the Antarctic Peninsula, Kellermann (1989a) reports that pelagic L. larseni grow to greater than $50 \mathrm{~mm}$ by their second summer (February/early March). Growth over winter must slow considerably from the summer. Growing at summer rates, L. larseni would grow to over $90 \mathrm{~mm}$ by the end of October (using the hatch size, hatch date, and growth rate parameters measured in this study). Instead, Kellermann (1989a) reports that peninsular L. larseni reach only 37 to $40 \mathrm{~mm}$ by late October/ early November Winter conditions are apparently more favorable for growth in waters around South Georgia; Efremenko (1979) has reported pelagic juvenile L. larseni 54 to $59 \mathrm{~mm}$ long in August. The month and size at which $L$. larseni juveniles finally take up a demersal existence are unknown.

A larger size at settlement is at least in part the result of the ability of winter larvae to continue feeding in the water column during the winter months. During summer, Gobionotothen gibberifrons and Lepidonotothen larseni larvae are both concentrated within the upper $30 \mathrm{~m}$ (Wörner \& James 1981, North 1988) and have similar diets, preying upon copepods, calanoid copepod eggs, and euphausiid eggs and furcilia (Balbontín et al. 1986, Kellermann 1990, North \& Ward 1990). L. larseni remain truly pelagic over winter and do not settle to the benthic environment to re-enter the pelagic environment during their second summer. In winter, they are found throughout the water column $(0$ to $250 \mathrm{~m}$ ) but are most abundant in the upper $70 \mathrm{~m}$ (North 1988). While the winter diet of L. larseni has not been studied, North \& Ward $(1989,1990)$ have found the winter diets of other larval Nototheniidae to be dominated by adult copepods. They also found that, like $L$. larseni, the major prey species was concentrated within the upper $70 \mathrm{~m}$. Thus, the overwintering copepod stages are an available food source to which winter larvae have access and summer larvae do not.

The benefit that faster growth and development offer summer larvae is immediate; the time spent in the larval stage is minimized and exposure to the hazards of larval life is reduced. Small changes in growth and development stage duration are a major regulating mechanism of recruitment into the adult population (Houde 1987). The benefits of the winter development strategy may not be realized until after settlement. Reduced predation pressure and a competitive advantage over smaller, newly settling summer juveniles (both possible with settlement at a large size) and the ability to escape competitive pressure (settlement when competition is reduced; Kellermann \& Schadwinkel 1990) may be achieved with an extended pelagic period.

Testing these hypotheses will require knowing the mortality rates suffered by larvae before settlement and by juveniles after settlement. During the pelagic larval period, survivorship should be greater for summer larvae. After settlement, juvenile survivorship should be greater for species with winter larvae Unfortunately, there are few examples of repeated ichthyoplankton surveys within the same year which would allow estimations of larval mortality rates. Kellermann \& Kock (1988) took advantage of such an opportunity to document an exponential decline of Lepidonotothen larseni abundance over the summer 
months of $1977 / 78$. Also needed is an indication of whether summer and winter juveniles are competitors in the demersal environment and whether growth of winter larvae in the plankton exceeds the growth of newly settled summer juveniles over the winter months. Do winter juveniles truly have a size advantage at the time of settlement? Little of the ecology of newly settled juvenile fish has yet been studied in the Antarctic, and criteria for predicting juvenile success are not known.

Another test of these hypotheses will be to see how well the results of this study can be applied to the Notothenioidei in general. Are the hatch period, growth, and development traits of Gobionotothen gibberifrons and Lepidonotothen larseni common to all species with summer and winter larvae, respectively? Indeed, can all species be classified into one of the 3 described strategies: precocial larvae, altricial summer larvae, and altricial winter larvae? At present, the early life-histories of most Notothenioidei remain entirely unknown.

Acknowledgements. I am grateful to David Shafer, Georgia Tien, Mark Huntley, and Valerie Loeb for providing the samples; to Shannon Kayatani for help in the lab; and to Tina Carvalho and Marilyn Dunlap of the Pacific Biomedical Research Center Electron Microscope Facility. I would also like to thank the scientists and crew of the RV 'Professor Siedlecki', RV 'Polar Duke', and RV 'Surveyor' Finally, I am grateful for the good advice of Adi Kellermann; my thesis committee, Richard Young and Craig Smith; and my thesis advisor, Richard Radtke. This study was funded by National Science Foundation grants DPP 85-21017, OCE 84-15968, DPP-9123017, OCE9205936, DEB 93-22618, and AMLR. This is School of Ocean and Earth Science and Technology contribution number 4051.

\section{LITERATURE CITED}

Arnaud PM (1977) Adaptations within the Antarctic marine benthic ecosystem. In: Llano GA (ed) Adaptations within Antarctic ecosystems. Gulf Publishing Co. Houston, p $135-157$

Balbontín F, Garretón M, Neuling J (1986) Composición del alimento y tamaño de las presas en larvas de peces del estrecho Bransfield (SIBEX-Fase II-Chile). Ser Cient INACH 35:125-144

Campana SE (1989) Otolith microstructure of three larval gadids in the Gulf of Maine, with inferences on early life history. Can J Zool 67:1401-1410

Campana SE (1990) How reliable are growth back-calculations based on otoliths? Can J Fish Aquat Sci 47:2219-2227

Clarke A (1979) On living in cold water: k-strategies in Antarctic benthos. Mar Biol 55:111-119

Clarke A (1983) Life in cold water the physiological ecology of polar marine ectotherms. Oceanogr mar Biol A Rev 21 $341-453$

Clarke A (1988) Seasonality in the Antarctic marine environment. Comp Biochem Physiol 90B:461-473

Eastman JT (1991) Evolution and diversification of Antarctic notothenioid fishes. Am Zool 31:93-109

Eastman JT (1993) Antarctic fish biology: evolution in a unique environment. Academic Press, Inc, San Diego

Efremenko VN (1979) The larvae of six species of the family Nototheniidae from the Scotia Sea. J Ichthyol 19:95-104

Efremenko VN (1983) Atlas of fish larvae of the Southern Ocean. Cybium 7:1-74

El-Sayed SZ (1985) Plankton of the Antarctic seas. In: Bonner WN, Walton DWH (eds) Key environments-Antarctica. Pergamon Press, New York, p 135-153

Everson I (1984) Fish biology. In: Laws RM (ed) Antarctic ecology, Vol 2. Academic Press, London, p 491-532

Flegler-Balon C (1989) Direct and indirect development in fishes-examples of alternative life-history styles. In: Bruton MN (ed) Alternative life-history styles of animals. Kluwer Academic Publishers, Dordrecht, p 71-100

Hollander M, Wolfe DA (1973) Nonparametric statistical methods. John Wiley \& Sons, New York

Houde ED (1987) Fish early life dynamics and recruitment variability. Am Fish Soc Symp Ser 2:17-29

Hourigan TF, Radtke RL (1989) Reproduction of the Antarctic fish Nototheniops nudifrons. Mar Biol 100:277-283

Huntley M, Karl DM. Niiler P. Holm-Hansen O (1991) Research on Antarctic coastal ecosystem rates (RACER): an interdisciplinary field experiment. Deep Sea Res 38: 911-941

Jenkins GP, Davis TLO (1990) Age, growth rate, and growth trajectory determined from otolith microstructure of southern bluefin tuna Thunnus maccoyij larvae. Mar Ecol Prog Ser 63:93-104

Jones C (1986) Determining age of larval fish with the otolith increment technique. Fish Bull US 84:91-104

Kellermann A (1986) On the biology of early life stages of notothenioid fishes (Pisces) off the Antarctic Peninsula. Ber Polarforsch 31:149pp

Kellermann A (1989a) The larval fish community in the zone of seasonal pack-ice cover and its seasonal and interannual variability. Arch FischWiss 39:81-109

Kellermann A (1989b) Catalogue of early life stages of Antarctic notothenioid fishes. In: Kellermann A (ed) Identification key and catalogue of larval Antarctic fishes BIOMASS Scient Ser 10:45-136

Kellermann A (1990) Food and feeding dynamics of the larval Antarctic fish Nototheniops Jarseni. Mar Biol 106:159-167

Kellermann A, Kock KH (1988) Patterns of spatial and temporal distribution and their variation in early life stages of Antarctic fish in the Antarctic Peninsular region. In: Sahrage D (ed) Antarctic ocean and resources variability. Springer-Verlag, Berlin, p 147-159

Kellermann A, Schadwinkel S (1990) Winter aspect of the ichthyoplankton community in Antarctic Peninsula water. Polar Biol 11:117-127

Kock KH (1985) Marine habitats - Antarctic fish. In: Bonner WN, Walton DWH (eds) Key environments-Antarctica. Pergammon Press, New York, p 173-192

Kock KH (1992) Antarctic fish and fisheries. Cambridge University Press, Cambridge, England

Kock KH, Kellermann A (1991) Reproduction in Antarctic notothenioid fish. Antarct Sci 3:125-150

Loeb VJ (1991) Distribution and abundance of larval fishes collected in the western Bransfield Strait region, 1986-87. Deep Sea Res 38:1251-1260

Marshall NB (1953) Egg size in Arctic, Antarctic and deep-sea fishes. Evolution 7:328-341

May HMA, Jenkins GP (1992) Patterns of settlement and growth of juvenile flounder Rhombosolea tapirina determined from otolith microstructure. Mar Ecol. Prog Ser 79: 203-214

Moore DS, McCabe GP (1989) Introduction to the practice of 
statistics. WH Freeman and Company, New York

Nishimura A, Yamada J (1988) Geographical differences in early growth of walleye pollock Theragra chalcogramma, estimated by back-calculation of otolith daily growth increments. Mar Biol 97:459-465

North AW (1988) Distribution of fish larvae at South Georgia: horizontal, vertical, and temporal distribution and early life history relevant to monitoring year-class strength and recruitment. Scientific Committee for the Conservation of Antarctic Marne Living Resources Selected Scientific Papers 1987, CCAMLR, Hobart, Tasmania, p 105-137

North AW (1990) Ecological studies of Antarctic fish with emphasis on early development of inshore stages at South Georgia. PhD thesis, British Antarctic Survey, Marine Enviroment Research Council, Cambridge

North AW, Ward P (1989) Initial feeding by Antarctic fish larvae during winter at South Georgia. Cybium 13:357-364

North AW, Ward P (1990) The feeding ecology of larval fish in an Antarctic fjord, with emphasis on Champsocephalus gunnari. In: Kerry KR, Hempel G (eds) Antarctic ecosystems: ecological change and conservation. SpringerVerlag, Berlin, p 299-307

North AW, White MG (1987) Reproductive strategies of Antarctic fish. In: Kullander SO, Fernholm B (eds) Proceedings of the $V$ Congress of the European Ichthyological Society, Stockholm 1985. Swedish Museum of Natural History, Stockholm, p 381-390

Olson RR, Bosch I, Pearse JS (1987) The hypothesis of Antarctic larval starvation examined for the asteroid Odontaster validus. Limnol Oceanogr 32:686-690

Pearse JS, Bosch I (1986) Are the feeding larva of the commonest Antarctic asteroid really demersal? Bull mar Sci 39:477-484

Pearse JS, Bosch I, McClintock JB (1985) Contrasting modes of reproduction by common shallow-water Antarctic invertebrates. Ant J US 30:138-139

Pearse JS, McClintock JB, Bosch I (1991) Reproduction of Antarctic benthic marine invertebrates: tempos, modes, and timing. Am Zool 31:65-80

Penney RW, Evans GT (1985) Growth histories of larval redfish (Sebastes spp.) on an offshore Atlantic fishing bank determined by otolith increment analysis. Can J Fish Aquat Sci 42:1452-1464

Picken GB (1980) Reproductive adaptations of Antarctic benthic invertebrates. Biol J Linn Soc 14:67-75

Radtke RL, Hourigan TF (1990) Age and growth of the Antarctic fish Nototheniops nudifrons. Fish Bull US 88:557-571

Radtke RL, Targett TE (1984) Structural and chemical rhythmic patterns in the otoliths of the Antarctic fish Notothenia

This article was submitted to the editor larseni and their application to age determination. Polar Biol 3:203-210

Radtke RL, Targett TE, Kellermann A, Bell J, Hill K (1989) Antarctic fish growth: profile of Trematomus newnesi Mar Ecol Prog Ser 57:103-107

Ricker WE (1973) Linear regressions in fishery research J Fish Res Bd Can 30:409-434

Ruzicka JJ, Radtke RL (1995) Estimating the age of Antarctic larval fish from otolith microstructure using light and electron microscopy. Polar Biol 15:587-592

Secor DH, Dean JM, Baldevarona RB (1989) Comparison of otolith growth and somatic growth in larval and juvenile fishes based on otolith length/fish length relationships. Rapp P-v Réun Cons int Explor Mer 191:431-438

Sinque C, Koblitz S, Costa LM (1988) Geographical distribution and abundance of fish larvae off the Antarctic Peninsula during the SIBEX I (1984). Arq Biol Tecnol 34:515-526

Sinque C, Koblitz S, Costa LM (1990) Occurrence of Antarctic fish larvae in the southern Drake Passage and in the Bransfield Strait during SIBEX II (1985). Arq Biol Tecnol 33:81-89

Snedecor GW, Cochran WG (1980) Statistical methods. 7th edn. The lowa State University Press, Ames

Sokal RR, Rohlf FJ (1981) Biometry-the principles and practice of statistics in biological research, 2 nd edn. WH Freeman and Company, New York

Thomas RM (1983) Seasonal variation in the relationship between otolith radius and fish length in the pilchard off south west Africa. S Afr J mar Sci 1:133-138

Thorrold SR, Williams DMcB (1989) Analysis of otolith microstructure to determine growth histories in larval cohorts of a tropical herring (Herklotsichthys castelnaui). Can J Fish Aquat Sci 46:1615-1624

Thorson G (1950) Reproduction and larval ecology of marine bottom invertebrates. Biol Rev 25:1-45

White MG (1977) Ecological adaptations by Antarctic poikilotherms to the polar marine environment. In: Llano GA (ed) Adaptations within Antarctic ecosystems. Gulf Publishing Co. Houston, p 197-208

White MG (1991) Age determination of Antarctic fish. In: di Prisco G, Maresca B, Tota B (eds) Biology of Antarctic fish Springer-Verlag, New York, p 87-100

Wilson KH, Larkin PA (1982) Relationship between thickness of daily growth increments in sagittae and change in body weight of sockeye salmon (Oncorhnychus nerka). Can J Fish Aquat Sci 39:1335-1339

Wörner FG, James R (1981) Early life history stages of the Antarctic fish Notothenıa gibberifrons Lönnberg 1905 Rapp P-v Cons perm int Explor Mer 178:196

Manuscript first received: June 19,1995

Revised version accepted: October 2, 1995 